\title{
An Impaired Uptake of Glucosamine in Tunicamycin Resistant Chinese Hamster Ovary Cells
}

\author{
Atsuko Sehara, Tadashi Sudo and Kazukiyo Onodera* \\ Institute for Virus Research, Department of Tumor Virus, \\ Kyoto University, Sakyo-ku, Kyoto 606, Japan
}

Received February 5, 1981

\begin{abstract}
Tunicamycin resistant mutants $\left(\mathrm{TM}^{\mathrm{R}}\right)$ were isolated and characterized from Chinese hamster ovary cells. One feature of this $\mathrm{TM}^{\mathrm{R}}$ mutants was a marked decrease in incorporation of radioactive glucosamine, both into membrane glycoproteins and $\mathrm{G}$ protein of vesicular stomatitis virus.

The cellular uptake and incorporation into acid insoluble materials of various radioactive substances, including glucosamine, galactosamine, mannose, 2-deoxyglucose and leucine, was examined for the purpose of determination whether the reduced incorporation of radioactive glucosamine into glycoproteins. was due to a defect in the glycosylation step or decreased uptake of glucosamine by cells.

While incorporation of glucosamine and 2-deoxyglucose into acid insoluble fractions was reduced strikingly in the mutants, the incorporation of mannose and leucine were the same as in the parent cells.

The uptake of glucosamine in $\mathrm{TM}^{\mathrm{R}}$ cells was lower than that in the wild type cells, and the $K m$ value for glucosamine uptake differed between the mutants and wild type cells. There was no obvious difference in the uptake of 2-deoxyglucose and mannose.
\end{abstract}

Many investigators suggest that glycoproteins are involved in biological phenomena such as cell to cell recognition and adhesion, ${ }^{1)}$ control of cell growth, ${ }^{2,3)}$ differentiation; ${ }^{4)} \mathrm{em}$ bryogenesis ${ }^{5,6)}$ and so on. The role of sugar moieties of glycoproteins has been elucidated in several cases, for example, recognition of serum glycoproteins, ${ }^{7)}$ assimilation of lysosomal enzymes, ${ }^{8,9)}$ intracellular processing such as transport, secretion and degradation of glycoprotein $^{10 \sim 12)}$ and stabilization of glycoproteins. ${ }^{13,14)}$

The role of sugar moieties of the cell membrane glycoproteins, however, is still obscure. Tunicamycin, an anti-viral agent, has been shown to inhibit the synthesis of $N$-acetylglucosaminylpyrophosphoryl polyisoprenol

* Present address: Laboratory of Biochemistry, Department of Agricultural Chemistry, The University of Tokyo, Bunkyo-ku, Tokyo 113, Japan.

All reprint request should be sent to $\mathrm{K}$. Onodera.

Abbreviations: $\mathrm{TM}$, tunicamycin; $\mathrm{TM}^{\mathrm{R}}$, tunicamycinresistant; CHO, Chinese hamster ovary; VSV, vesicular stomatitis virus. required for the glycosylation of asparaginelinked glycoproteins. ${ }^{15,16)} \mathrm{We}$ have isolated tunicamycin resistant mutants $\left(\mathrm{TM}^{\mathrm{R}}\right)$, novel type of membrane mutants from Chinese hamster ovary cells, which showed several unique characteristics.

In addition to their resistance to the cytotoxic action of tunicamycin, they exhibited an altered shape, the reduction of membrane glycoproteins labeled by galactose- $\left[{ }^{3} \mathrm{H}\right]$ borohydride technique, cross resistance to phytohaemagglutinin, and the reduced incorporation of radioactive glucosamine into membrane glycoproteins and $\mathrm{G}$ protein of vesicular stomatitis virus (VSV). These properties strongly suggest that some alterations have occurred in the synthesis of glycoproteins. ${ }^{17}$

It is, however, unclear whether the reduction of incorporation of radioactive glucosamine into glycoproteins in the mutant cells is due to the decrease in glucosamine transport or attributable to alteration in the glycoprotein synthetic pathway. Therefore we have investigated the incorporation of radioactive 
substances into acid insoluble parts and the transport of radioactive glucosamine as well as mannose, 2-deoxyglucose and galactosamine.

We will show that the uptake system of glucosamine which is presumably identical with the glucose uptake system is glycoprotein in nature and that an alteration in the synthetic pathway of glycoproteins may affect the glucosamine uptake system in the mutant cells.

\section{MATERIALS AND METHODS}

Cells and cell cultures. The parent Chinese hamster ovary cells (CHO) obtained by courtesy of Dr. Siminovitch, University of Toronto and auxotroph for glycine, adenosine and thymidine were designated Gat ${ }^{-} \mathrm{CHO}(\mathrm{B}-2)$. Tunicamycin resistant mutants $\left(\mathrm{TM}^{\mathrm{R}}\right)$ were isolated from $\mathrm{CHO}$ cells as previously described. ${ }^{17}$ ) The mutant clones described in the present paper are $\mathrm{TM}^{\mathrm{R}} 214$ and $\mathrm{TM}^{\mathrm{R}} 205$. The parent and mutant cells were maintained either in suspension or in monolayer culture at $37^{\circ}$ in complete $\alpha$-medium supplemented with fetal calf serum (Flow Laboratory, Rockville, Maryland) and with antibiotics (penicillin $\mathrm{G}$ and kanamycin).

Measurement of sugar uptake. The cells at exponential growth phase in suspension culture (about $3 \times 10^{5}$ cells $/ \mathrm{ml}$ ) were harvested, washed twice with phosphate buffered saline (PBS, pH 7.4) and suspended in PBS. About $10^{5}$ cells were mixed with $1 \mu \mathrm{Ci}$ of radioactive substances and the final concentration was adjusted as indicated in each experiment. The reaction mixture (total volume, $0.5 \mathrm{ml}$ ) was incubated for 10 minutes at $37^{\circ}$. The reaction was stopped by the addition of $5 \mathrm{ml}$ of ice-cold PBS and the cells were harvested by centrifugation. The cells were washed twice with PBS and then solubilized with $0.1 \mathrm{~N}-\mathrm{NaOH}$ for the measurement of radioactivity and protein. The radioactivity was counted in 10 volumes of PCS (Amersham, liquid scintillant for aqueous sample) on a Beckman LS-7000 liquid scintillation counter. Sugar uptake activity was expressed as $n$ moles of substrate/mg of protein/minute. Protein was determined by Lowry procedure. $^{18)}$

Decay of sugar uptake activity in the tunicamycin treated cells. The wild type cells growing exponentially in suspension culture were incubated in the medium with or without $0.2 \mu \mathrm{g} / \mathrm{ml}$ of tunicamycin for the intervals indicated. Cells were harvested at each interval and washed with PBS. The sugar uptake activity of each sample was measured as described above.

Incorporation of radioactive substances into acid insoluble fraction. Cells were plated in $60 \mathrm{~mm}$ Falcon petri dishes in $\alpha$ medium and labeled with radioactive $\left[{ }^{3} \mathrm{H}\right]-$ mannose $(5 \mu \mathrm{Ci} / \mathrm{ml}),\left[{ }^{3} \mathrm{H}\right]$-glucosamine $(3 \mu \mathrm{Ci} / \mathrm{ml})$ and $\left.{ }^{3} \mathrm{H}\right]$-leucine $(2 \mu \mathrm{Ci} / \mathrm{ml})$ for 5 hours. Cells were harvested at each interval, washed with PBS, resuspended in PBS, and trichloroacetic acid was added to a final concentration of $5 \%$. Acid precipitable materials were filtered on glass fiber and counted. In the case of 2-deoxyglucose, about $2 \times 10^{5}$ cells were suspended in $\alpha$-medium containing $1 \mathrm{~mm}$ glucose and $1.6 \mu \mathrm{Ci} / \mathrm{ml}\left[{ }^{3} \mathrm{H}\right]$-2-deoxyglucose with or without $0.2 \mu \mathrm{g} / \mathrm{ml}$ of tunicamycin. After incubation in roller culture for the time indicated cells were harvested, washed and suspended in $1 \mathrm{ml}$ of PBS. $0.8 \mathrm{ml}$ of the suspension was precipitated with $5 \mathrm{ml}$ of $5 \%$ of trichloroacetic acid (TCA) in the cold and radioactivity collected on glass fiber was counted. $0.2 \mathrm{ml}$ of cell suspension was used for protein determination.

Tunicamycin was the gift of Dr. G. Tamura, The University of Tokyo. D-[6- $\left.{ }^{3} \mathrm{H}(\mathrm{N})\right]-\mathrm{G}$ lucosamine hydrochloride was purchased from New England Nuclear. D- $\left[2-{ }^{3} \mathrm{H}\right]-$ Mannose, 2-deoxy-D- $\left[1-{ }^{3} \mathrm{H}\right]$-glucose, D- $\left[1-{ }^{14} \mathrm{C}\right]-$ galactosamine hydrochloride, and $1-\left[4,5-{ }^{3} \mathrm{H}\right]$-leucine were purchased from Amersham Searle.

\section{RESULTS}

\section{Incorporation of radioactive substrates into acid} insoluble part of the cells

In order to know whether the decreased incorporation of radioactive glucosamine both into membrane glycoprotein and $G$ protein of VSV is specific for glucosamine, we examined the incorporation of other radioactive substrates including D-mannose, 2-deoxy-Dglucose and L-leucine into acid insoluble parts in wild type and $\mathrm{TM}^{\mathrm{R}}$ cells. All the experiments were carried out in $\alpha$-medium supplemented with radio active compound. As shown in Fig. 1, the marked reduction of incorporation of glucosamine and 2-deoxyglucose was observed in $\mathrm{TM}^{\mathrm{R}}$ cells, whereas no reduction of mannose and leucine was observed in the mutant cells. Moreover, the incorporation of $\left[{ }^{3} \mathrm{H}\right]$-2-deoxyglucose into acid insoluble parts of wild type cells was markedly inhibited by the addition of $0.2 \mu \mathrm{g} / \mathrm{ml}$ of tunicamycin and this process is resistant to tunicamycin in the mutant (Fig. 2).

\section{Uptake of glucosamine}

To investigate whether the observed reduction of glucosamine incorporation into glycoproteins in $\mathrm{TM}^{\mathrm{R}}$ cells is due to the decrease in glucosamine transport, we examined 

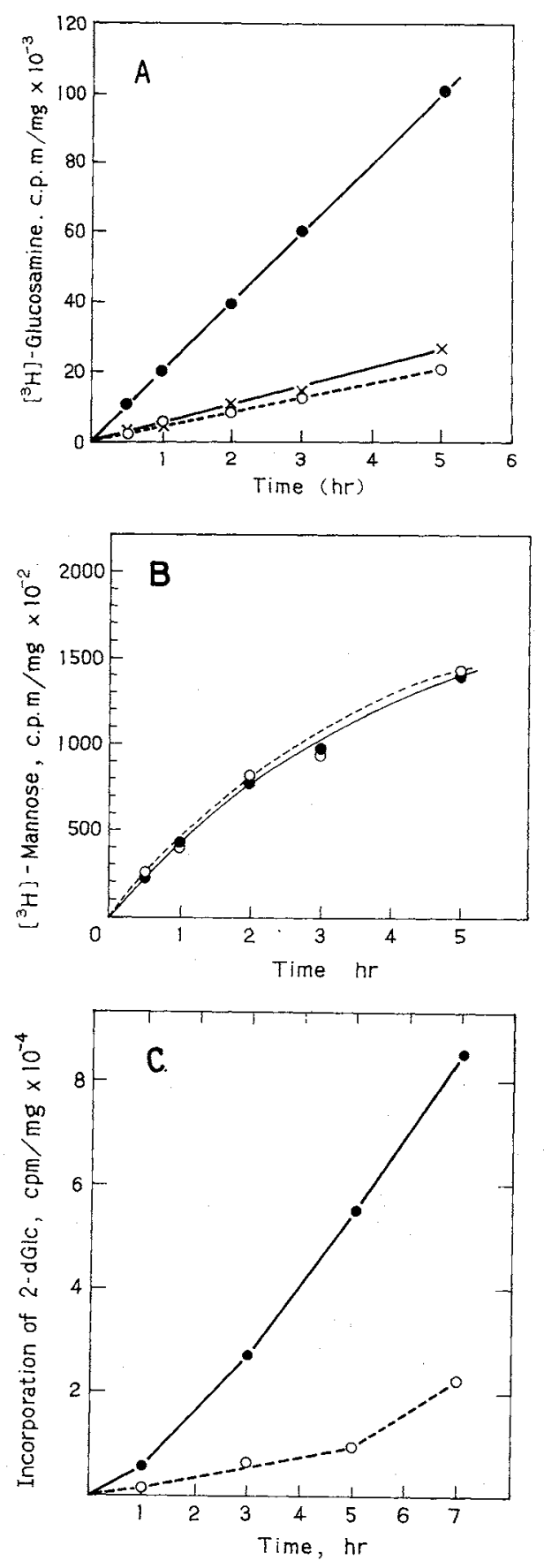

the uptake of glucosamine in the rapidly growing cells of wild type and $\mathrm{TM}^{\mathrm{R}}$ cells. The uptake of glucosamine was studied as a function of time at the concentration of $1 \mathrm{~mm}$ of glucosamine. The rate of uptake of glucosamine was constant for at least 10 minutes in

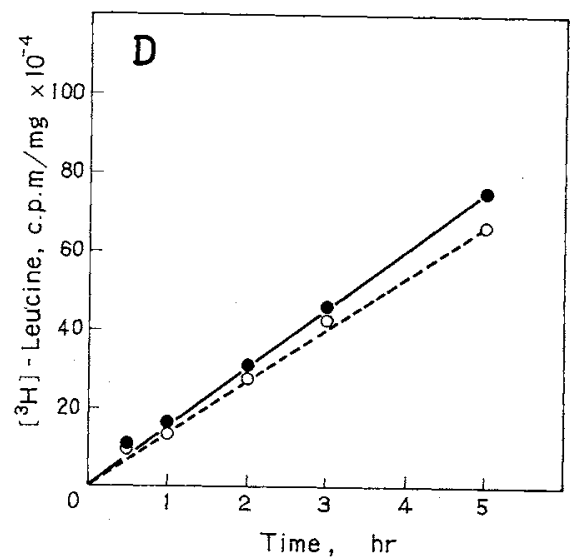

FIG. 1. Incorporation of $\left[{ }^{3} \mathrm{H}\right]$-Labeled Substrates, (A) Glucosamine, (B) Mannose, (C) 2-Deoxyglucose, and (D) Leucine, into Acid Insoluble Fraction of Wild Type and TM $^{\mathrm{R}} 214$ Cells.

Exponentially growing cells in suspension culture were incubated in the medium containing respective $\left[{ }^{3} \mathrm{H}\right]-$ labeled substrate. After $1 \sim 5$ hours incubation, the cells were harvested, washed with PBS, precipitated with $5 \%$ TCA in the cold, and $\mathrm{cpm} / \mathrm{mg}$ protein were determined as described in Materials and Methods. Wild type cells (-O-); TM 214 (---O--); TM 205 cells (-メ-).

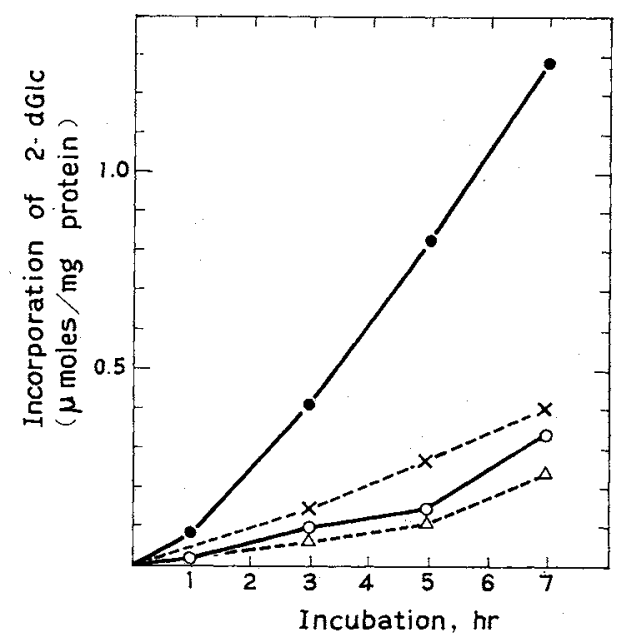

Fig. 2. Effect of Tunicamycin on the Incorporation of $\left[{ }^{3} \mathrm{H}\right]$-2-Deoxyglucose into Acid Insoluble Fraction.

Wild type cells were incubated in the medium containing $\left[{ }^{3} \mathrm{H}\right]$-2-deoxyglucose with or without $0.2 \mu \mathrm{g} / \mathrm{ml}$ tunicamycin. After $1 \sim 7$ hours incubation, the cells washed with PBS were precipitated with $5 \%$ TCA in the cold, and $\mathrm{cpm} / \mathrm{mg}$ protein were determined as described in Materials AND Methods. Without tunicamycin ($-\mathrm{O}-)$; with tunicamycin $(--\times-\cdots, \cdots \triangle \cdots)$. Wild type cells (-O--, -- $\times---)$; $\mathrm{TM}^{\mathrm{R}} 214\left(-\mathrm{O}-,--\triangle_{---)}\right.$. 


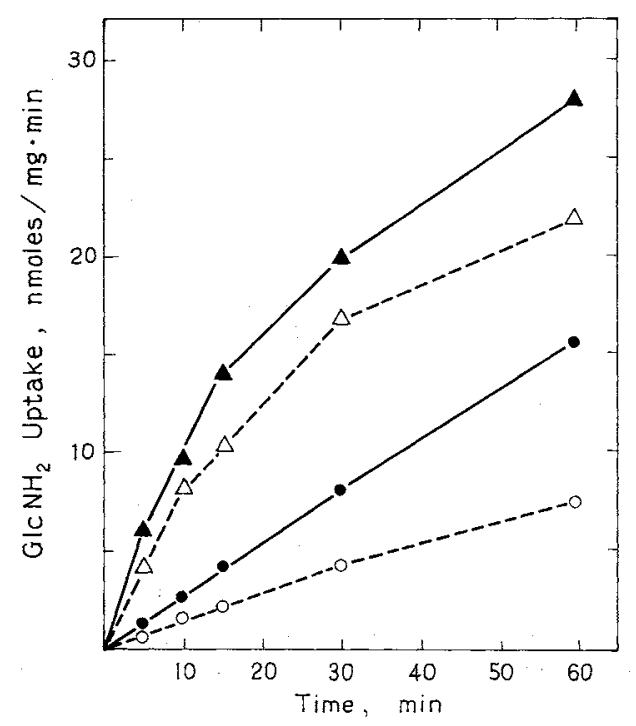

Fig. 3. Time Course of Glucosamine Uptake in Wild Type and $\mathrm{TM}^{\mathrm{R}} 214$ Cells.

Exponentially growing cells in suspension culture were washed with PBS and incubated in $0.5 \mathrm{ml}$ PBS containing $\left.{ }^{3} \mathrm{H}\right]$-glucosamine of $1 \mathrm{~mm}$ and $10 \mathrm{mM}$ for $5 \sim 60$ minutes. The measurement of intracellular radioactivity was carried out as described in Materials and Methons. $1 \mathrm{~mm}$ glucosamine (-O-, --- $\left.\mathrm{O}_{---}\right) ; 10 \mathrm{mM}$ glucosamine $(-\mathbf{A}-,--\triangle--)$. Wild type cells $(-\mathbf{-},-\mathbf{A}-) ; \mathrm{TM}^{\mathrm{R}}$ 214 cells $\left(--\mathrm{O}^{---},--\triangle^{---}\right)$.

the concentration range between $0.1 \mathrm{mM} \sim$ $10 \mathrm{~mm}$ of glucosamine (Fig. 3; data shown at the concentration of $1 \mathrm{~mm}$ and $10 \mathrm{~mm}$ of glucosamine). The uptake both in $\mathrm{TM}^{\mathrm{R}} 205$ and $\mathrm{TM}^{\mathrm{R}} 214$ cells was obviously less than that in wild type cells, while such a difference was not seen at $10 \mathrm{~mm}$ glucosamine. To confirm this, the rate of glucosamine uptake versus glucosamine concentration was determined in 10 minutes of reaction (Fig. 4). It apparently followed the Michaelis-Menten kinetics up to approximately $10 \mathrm{~mm}$ glucosamine. When the substrate concentration is too high, simple diffusion or nonspecific uptake should be taken into consideration. ${ }^{19}$ ) Therefore, we limited the concentration of the substrate to $10 \mathrm{~mm}$ of glucosamine for the Lineweaver-Burk plots. The $K m$ values appeared to differ between wild type and $\mathrm{TM}^{\mathrm{R}}$ cells, being estimated to be $6 \mathrm{~mm}$ and $13 \mathrm{~mm}$, respectively. The $K m$ value of glucosamine
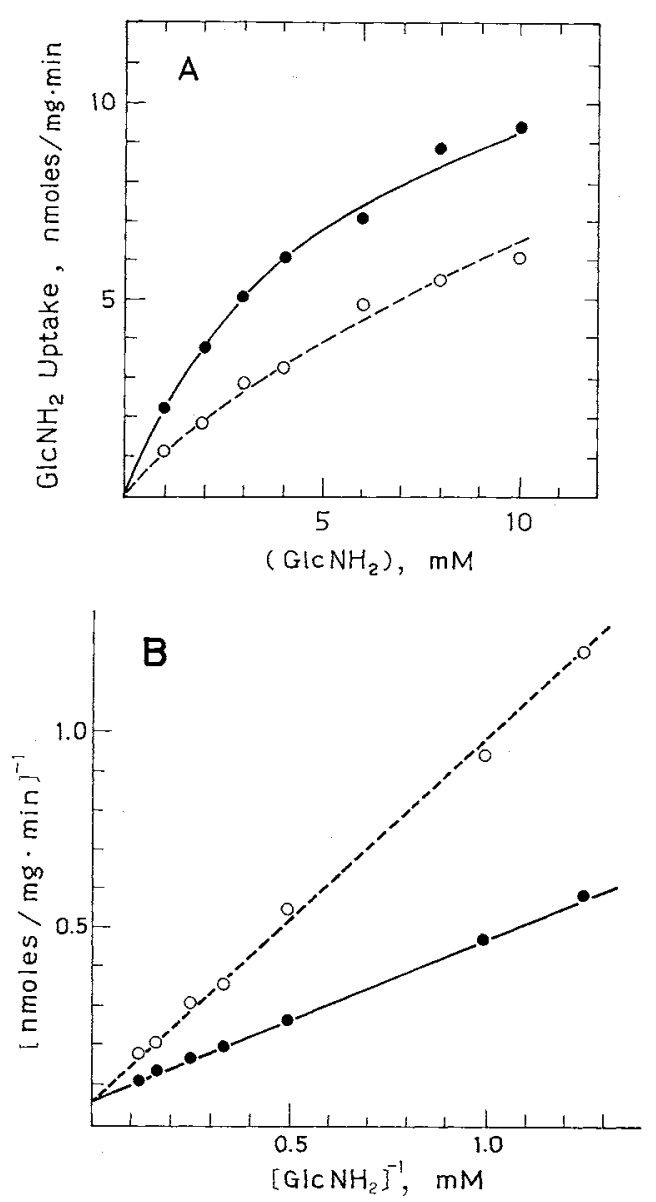

FIG. 4. (A) Uptake Rates of Glucosamine in Wild Type and $\mathrm{TM}^{\mathrm{R}} 214$ Cells.

Glucosamine uptake was determined for 10 minutes at $37^{\circ}$ in PBS containing $1 \mu \mathrm{Ci}$ glucosamine at the concentration between $1 \mathrm{~mm}$ and $10 \mathrm{~mm}$. Values are the average of three duplicate experiments. Wild type cells (-O-); $\mathrm{TM}^{\mathrm{R}} 214$ cells (--. O--).

(B) Lineweaver-Burk Plot of glucosamine Uptake Shown in Fig. (A). Wild type cells (- - ) TM $^{\mathrm{R}} 214$ cells $(--\mathrm{O}--)$.

uptake in $\mathrm{TM}^{\mathrm{R}} 205$ cells was about $7 \mathrm{mM}$ (data not shown).

\section{Uptake of 2-deoxyglucose and other sugars}

In order to determine whether the observed reduction of the uptake of sugars is specific for glucosamine, we examined the uptake of 2deoxyglucose, galactosamine and mannose. As shown in Fig. 5, no obvious difference was seen between mutants and wild type cells in 2 - 


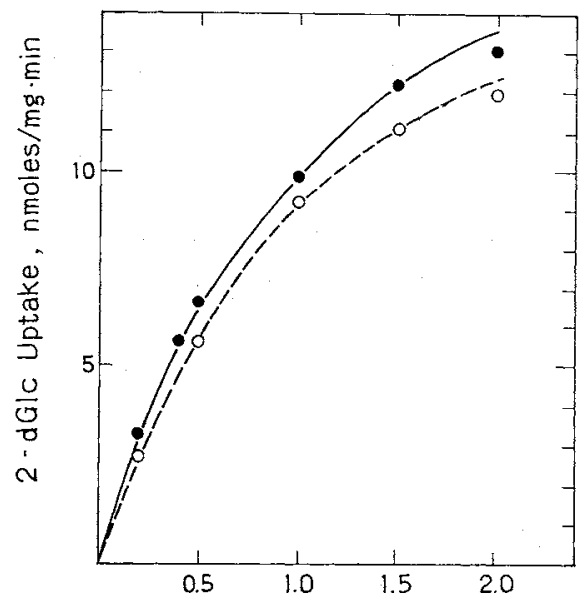

Fig. 5. Uptake Rate of 2-Dexoyglucose in Wild Type and $\mathrm{TM}^{\mathrm{R}} 214$ Cells.

2-Dexoyglucose uptake was determined for 10 minutes at $37^{\circ}$ in PBS containing $1 \mu \mathrm{Ci} 2$-deoxyglucose at the concentration between $0.1 \mathrm{~mm}$ and $2 \mathrm{~mm}$. The measurement of intracellular radioactivity was carried out in the same way as glucosamine. Wild type cells (-O-); TM ${ }^{\mathrm{R}} 214$ cells $(--\bigcirc--)$.

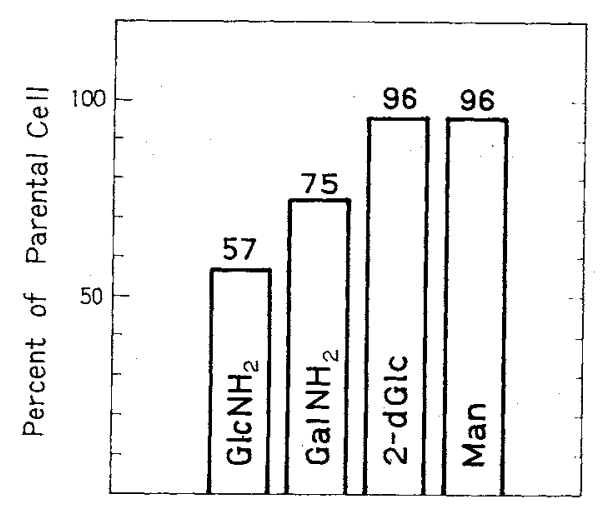

FIG. 6. Uptake Rate of Sugars in $T M^{\mathrm{R}} 214$ Cells Compared with That in Wild Type Cells.

The uptake of glucosamine, galactosamine, 2-deoxyglucose, or mannose was determined for 10 minutes at $37^{\circ}$ in PBS containing $1 \mu \mathrm{Ci}$ respective substrate of $0.2 \mathrm{mM}$. The uptake rate in $\mathrm{TM}^{\overline{\mathrm{R}}} 214$ was expressed as the percentage of that in wild type cells.

deoxyglucose uptake. To confirm that the observed results were real and not derived from the physiological condition of the cells, the uptake of glucosamine, galactosamine, 2deoxyglucose and mannose were examined at the concentration of $0.2 \mathrm{mM}$ using the same preparation of the cells. Glucosamine uptake

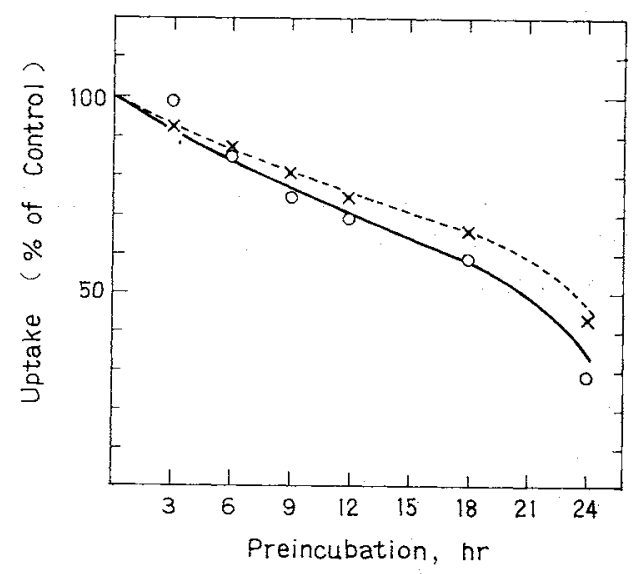

FIG. 7. The Decay of Sugar Uptake in the Tunicamycin Treated Cells.

Exponentially growing wild type cells in suspension culture were incubated in the medium with or without $0.2 \mu \mathrm{g} / \mathrm{ml}$ tunicamycin for $3 \sim 24$ hours. After washing twice with PBS, the uptake rate of 2-deoxyglucose and glucosamine was measured as described in MATERIALS AND METHODS.

The uptake in tunicamycin treated cells was expressed as the percentage of control. Glucosamine uptake ( $-\mathrm{O}-$ ); 2-deoxyglucose uptake (--- $\times---)$.

in $\mathbf{T M}^{\mathrm{R}}$ cells was significantly lower than that in wild type cells while no difference was seen in 2-deoxyglucose or mannose (Fig. 6). The difference in the uptake of galactosamine as well as glucosamine indicates that the alteration in the ability of sugar uptake in $\mathrm{TM}^{\mathrm{R}}$ cells may be rather specific for hexosamine.

\section{Effect of tunicamycin pretreatment on the rate}

of glucosamine and 2-deoxyglucose uptake

Olden et al. have shown that glycosylation of membrane carrier glycoprotein is necessary for the uptake of 2-deoxyglucose. ${ }^{20)}$ To clarify whether the uptake of glucosamine is also mediated by glycoprotein carrier, we examined the effect of tunicamycin pretreatment on both the uptake rates of glucosamine and 2-deoxyglucose. When wild type cells were incubated with tunicamycin for various intervals, the uptake of both sugars were decreased in a similar fashion. Cells remained viable by dye exclusion test under this condition. This means that glycosylation of the carrier proteins is also required for the transport of glucosamine 
(Fig. 7).

\section{DISCUSSION}

One of the prominent features of $\mathrm{TM}^{\mathrm{R}}$ mutant cells was the marked decrease in the incorporation of radioactive glucosamine into membrane glycoproteins and $\mathrm{G}$ protein of VSV. To clarify whether the reduction of $\left[{ }^{3} \mathrm{H}\right]$ glucosamine incorporation into glycoproteins was derived from a defect in the glycosylation pathway or to the decreased uptake of glucosamine in the mutant cells, we examined the uptake rate of glucosamine in $\mathrm{TM}^{\mathrm{R}}$ mutant cells in detail. As shown above, the rate of glucosamine uptake in the mutant cells was about $60 \%$ of the wild type cells at low glucosamine concentration, while no obvious difference was observed in the uptake of 2deoxyglucose and mannose. Therefore, the observation previously described of the markedly decreased incorporation of radioactive glucosamine into membrane and $G$ glycoprotein of VSV could be at least partially explained by the reduction of glucosamine uptake.

In order to exclude the possibility that the decrease in glucosamine uptake was due only to the larger pool size of glucosamine in $\mathrm{TM}^{\mathrm{R}}$ mutant cells compared to that of wild type cells, which might lower the activity of glucosamine uptake in. $\mathrm{TM}^{\mathrm{R}}$ cells, we measured the size of glucosamine in both types of cells in the following way. The cells incubated in the medium containing $\left[{ }^{3} \mathrm{H}\right]$-uridine for $30 \mathrm{~min}$ utes were extracted with $70 \%$ ethanol and the UDP- $N$-acetylglucosamine and UDP-glucose which were produced were analyzed by paper chromatography. The ratio of UDP- $N$ acetylglucosamine to UDP-glucose as measured by counts of radioactivity was somewhat smaller in both types of mutant cells, indicating that the pool size of glucosamine in the mutant cells was also smaller even though the pool size of glucose was the same as in wild type cells (data not shown). Therefore, the decreased glucosamine uptake in the mutant cells would not be a secondary effect caused by the larger pool size of glucosamine.

It is noteworthy that the increase in the $\mathrm{Km}$ value for glucosamine uptake occurred without a change in the $V_{\max }$ in the mutant cells. In this context, it is pertinent to refer to the properties of chick embryo fibroblast cells that were treated with tunicamycin. ${ }^{20)}$ In the cells pretreated with tunicamycin, the $V_{\max }$ value decreased without a change in the $K m$ value, and in this case, the incorporation of mannose into acid insoluble parts was also inhibited.

On the other hand, much less $\left[{ }^{3} \mathrm{H}\right]-2-$ deoxyglucose, which $\mathrm{TM}^{\mathrm{R}}$ cells transport normally, was incorporated into acid insoluble parts of the cells as compared with the wild type cells. Although 2-deoxyglucose is thought to be poorly metabolized, it has been reported that phosphorylated 2-deoxyglucose is further converted to guanosine diphosphodeoxyglucose in part and is incorporated into glycoprotein and glycolipids in yeast and mammalian cells. ${ }^{21)}$ As shown in Fig. 2, the incorporation of $\left[{ }^{3} \mathrm{H}\right]$-2-deoxyglucose into acid insoluble parts was inhibited by $0.2 \mu \mathrm{g} / \mathrm{ml}$ of tunicamycin in the wild type cells, whereas that in the mutant was not inhibited. This indicates that $\left[{ }^{3} \mathrm{H}\right]$-2-deoxyglucose was incorporated into the carbohydrate moieties of glycoproteins through a pathway which was sensitive to tunicamycin. This also strongly suggests that some defects have occurred in the biosynthetic pathway of glycoproteins in the mutants. Further biochemical analysis is needed for precise characterization of the mutant cells.

The fact that the uptake of 2-deoxyglucose needs glycosylation of glycoproteins ${ }^{20)}$ and that the glucose transport system purified from human erythrocytes is a glycoprotein containing sialic acid have been reported. ${ }^{22}$ ) Since the glucosamine transport system also needs glycosylation as shown above, it is conceivable that the alteration in the synthetic pathway of glycoprotein affects the structures of glycoproteins, one of which is involved in glucosamine transport in the mutant cells. Though glucosamine is generally thought to be transported by the same carrier as 2- 
deoxyglucose and mannose in mammalian cells, ${ }^{23)}$ the transport system specific for glucosamine was reported in a kind of yeast. ${ }^{24)}$ In our mutant cells, the uptake of glucosamine and galactosamine was affected while the uptake of neutral sugars seemed to be normal.

Since the target enzyme of tunicamycin is the enzyme involved in the formation of a lipid-oligosaccharide intermediate, the study of its formation in vivo would shed some light on the properties of our mutant cells. Experiments along this line will be published in a subsequent paper.

Acknowledgments. The authors would like to express thanks to Dr. G. Tamura for the generous gift of tunicamycin, and Dr. L. Siminovitch for supplying Chinese hamster ovary cell lines. The work was supported by a Grant-in-Aid for Scientific Research and Cancer Research from the Ministry of Education, Science and Culture of Japan.

\section{REFERENCES}

1) J. M. Pouyssegur, M. Willingham and I. Pastan, Proc. Natl. Acad. Sci. U.S.A., 74, 243 (1977).

2) K. Onodera and R. Sheinin, J. Cell Sci, 7, 337 (1970)

3) G. L. Nicolson, Biochim. Biophys. Acta, 458, 1 (1976).

4) C. Town and E. Stanford, Proc. Natl. Acad. Sci. U.S.A., 76, 308 (1979).

5) M. A. H. Surani, Cell, 18, 217 (1979).

6) T. Muramatsu, G. Gachelin, J. F. Nicolas, H. Condamine, H. Jacob and F. Jakob, Proc. Natl. Acad. Sci., U.S.A., 75, 2315 (1978).
7) G. Ashwell and A. G. Morell, "Advance in Enzymology," Vol. 41, ed. by Meister, John Wiley \& Sons, New York, 1974, p. 99.

8) J. Distler, V. Hieber, G. Sahagian, R. Schmickel and G. W. Joudian, Proc. Natl. Acad. Sci. U.S.A., 76, 4235 (1979).

9) M. R. Natowicz, Y. Chi, O. H. Lowry and W. S. Sly, Proc. Natl. Acad. Sci. U.S.A., 76, 4322 (1979).

10) K. Olden, R. M. Pratt and K. M. Yamada, Cell, 13, 461 (1978)

11) O. H. Lowry, N. J. Rosebrough, A. L. Farr and R. J. Randall, J. Biol. Chem., 93, 265 (1951).

12) R. Leavitt, S. Schlesinger and S. Kornfeld, J. Biol. Chem., 252, 9018 (1977).

13) J. Fujisawa, Y. Iwakura and Y. Kawade, J. Biol. Chem., 253, 8677 (1978).

14) F. K. Chu, R. B. Trimble and F. Maley, J. Biol. Chem., 253, 8691 (1978).

15) A. Takatsuki, K. Kohno and G. Tamura, Agric. Biol. Chem., 39, 2089 (1975).

16) J. S. Tkacz and J. O. Lampen, Biochem. Biophys. Res. Commun., 65, 248 (1975).

17) T. Sudo and K. Onodera, J. Cell Physiol, 101, 149 (1979).

18) O. H. Lowry, N. J. Rosebrough, A. L. Farr and R. J. Randall, J. Biol. Chem., 93, 265 (1951).

19) R. F. Kletzien and J. F. Perdue, J. Biol. Chem., 249, 3366 (1974)

20) K. Olden, R. M. Pratt, D. Jaworski and K. M. Yamada, Proc. Natl. Acad. Sci. U.S.A., 76, 791 (1979).

21) S. Steiner, R. J. Courtney and J. L. Melnick, Cancer Res., 33, 2402 (1973).

22) D. C. Sigin and P. C. Hinkle, J. Supra, Struc., 8, 447 (1978).

23) S. G. Lee and F. Lipmann, Proc. Natl. Acad. Sci. U.S.A., 74, 163 (1977).

24) S. Balraj and A. Datta, Biochim. Biophys. Acta, 557, 248 (1979). 